\title{
Adoption of Improved Rice Production Technologies among Youth Farmers in Gbako Local Government Area, Niger State
}

\author{
Umar, S. I., Ndanitsa, M. A. and Olaleye, S. R. \\ Dept of Agric. Economics \& Extension Technology, F. U. T. Minna \\ E-mail: iumarsheshi@yahoo.com
}

\begin{abstract}
The study examined the adoption of improved rice production technologies by youths in Gbako L.G.A. of Niger State. To achieve the study objectives, 74 youth rice farmers were randomly selected from eight villages in the area using simple random technique. Data collected were analysed using descriptive statistics and chi-square test. Findings showed that fertilizer application was adopted by $79.72 \%$ of the respondents, while the least technology adopted was plant spacing practice as reported by $18.92 \%$ of the respondents. Results of the study also revealed that adoption of rice technologies had increased output/income, encouraged children education and improved health condition of the respondents. The study equally indicated that preferences for grains quality and straw yield are some of the reasons for adopting improved rice varieties. Furthermore, income, extension contact and social participation had significant relationship with adoption $(p<0.05)$. The major constraints identified include pest invasion reported by 55.41 percent, followed by inadequate knowledge on plant spacing and planting time with $45.95 \%$ response and grazing problem as indicated by $25.68 \%$ of the respondents. Based on the findings, it was suggested that more promising rice varieties that will meet the respondents' preference and requirement for grains and straw yield should be developed. Moreso, a team approach to rice extension should be introduced to find holistic solution to the problems of pest and inadequate knowledge.
\end{abstract}

\section{INTRODUCTION}

One of the major reasons attributed to the low growth of the Nigeria economy is the slow growth of the agricultural sector, which is characterized by rising food prices, increase in food import and inadequate raw material which is attributed especially to the use of inappropriate technology (Central Bank of Nigeria [CBN], 1999). The adoption of improved technologies can lead to increase productivity and higher income to farmers. This could, consequently lower the prices of agricultural products and generate greater economy efficiency and over-all growth in the national economy.

The system of rice production in Nigeria is mainly through traditional methods which have been in existence for many decades. The average rice yield on farmer's field had been described as generally lower (1.8-2.0 tones/ha) than commonly obtained on experimental plots in lowland ecology (3.5-4.5 tones/ha) (Imolehin, 2000).

Commonly cited constraints for this poor outputs includes inadequate use of improved varieties and new plant date practices, poor weed control, lack of inorganic fertilizer application, poor 


\section{Journal of Agricultural Extension}

Vol. 13 (1) June, 2009

tillage operation and processing. It is against this background that National Cereals Research Institute (NCRI) Baddegi in collaboration with International Institute of Tropical Agriculture (IITA) and West Africa Rice Development Association (WARDA) developed and extended a number of improved rice production technologies to farmers to increase rice production, improve farm income and save the country scarce foreign exchange in rice imports. But the question is, to what extent have the farmers adopted rice technologies disseminated? Other questions which the research will provide answers for includes: what are the socio-economic benefits of adoption to the farmers and what are the constraints faced. The specific objectives of the study are to:

(i) determine the extent of adoption of rice technologies ;

(ii) examine the socio-economic benefits of adoption of rice technologies to the respondents;

(iii) determine relationship between adoption and respondent's socio-economic characteristics; and

(iv) determine constraints associated with production and adoption of improved rice production technologies.

\section{METHODOLOGY}

\section{The Study Area}

Gbako Local Government Area is located in Guinea Savannah vegetation zone of Nigeria. In the area, rice is cultivated mostly under rain-fed conditions. The area receives annual rainfall of between $1000-1500 \mathrm{~mm}$, which occurs from mid-April to November.

Average monthly temperature ranges from $23^{\circ} \mathrm{C}$ to $29^{\circ} \mathrm{C}$. The area falls within Latitude $8^{0}-10^{\circ} \mathrm{N}$ and Longitudes $3^{0}-8^{0}$ East, with estimated population of 127,466 people as revealed by 2006 national population census. Soils are predominantly light and well drained, while fadama and depressions are accessible to many families. Crop and livestock farming is the major occupation of the people (Niger State Government Diary [NGSG], 2003).

\section{Data Collection}

Simple random sampling technique was used in selecting eight villages from a sampling frame of 20 villages that are directly involved in rice production in the area. The selected villages are Edozhigi, Etsu-Audu, Gusadi, Potun, Lemu, Saganuwa, Gbangba, and Wasagi. In all, not less than $40 \%$ of the youth farmers of these villages were randomly selected, resulting in a total of 74 farmers that were interviewed with the aid of an interview schedule. The respondents were asked of their socio-economic characteristics and adoption/production constraints they faced. Similarly, the socio-economic benefits of adoption of rice technologies on farmers' yield, income, health and children education was recorded. Information was also collected on technology adoption.

\section{Measurement of Variables}

The dependent variable of the study is the adoption of existing improved rice production technologies (use of improved rice varieties, plant spacing practice, new tillage operation, fertilizer application, use of chemical for weed control and milling/processing technology), among farmers in the area. It was measured using stages of adoption: Awareness stage 1 point, interest stage 2 points, evaluation stage 3 points, trial stage 4 points and adoption stage 5 points. The maximum point for adoption is 30 points while the minimum point is 6 points. The independent variables are age, income and household size measured in years, naira and 
number respectively, while formal education was measured by the number of years of formal schooling, Social participation was determined based on level of involvement in formal organizations and scores were allocated as: none member -0 , part-time member -1 and full-time member - 2 and Extension contact was measured based on frequency of contact with extension agents and scores were allocated as: no contact -0 ,occasional contact -1 and regular contact -2 .

\section{Data Analysis}

Descriptive statistical tools of frequency distribution and percentages were used in achieving objectives one, two and four. While chi-square test was used to determine the relationship between socio-economic characteristics of respondents and adoption of the existing technologies at $0.05 \%$ level of significance (objective three).

\section{RESULTS AND DISCUSSION}

\section{Adoption of improved rice production technologies}

The data in Table 1 shows that almost $80.00 \%$ of the respondents adopted fertilizer application. Majority of the respondents (77.02\%) also adopted improved rice varieties, followed by use of chemical for weed control with $60.81 \%$ response. The following are in this order: milling/processing technology (43.24\%) and new tillage operation (31.08\%) while the least adopted technology was plant spacing practice as indicated by only $18.92 \%$ of the respondents. The technologies with low adoption score could mean that the respondents have not known their relevance to their production. However, low adoption of some of the technology could just be a matter of choice, without tangible reasons attached to it. This suggests the need for more awareness to encourage the farmers to adopt the entire production package extended to them for maximum benefit.

\section{TABLE 1: Adoption of improved rice production technologies by the respondents}

\begin{tabular}{lcc} 
Rice Production Technologies & Frequency & Percentage \\
\hline Improved rice varieties & 57 & 77.02 \\
Plant spacing practice & 14 & 18.92 \\
New tillage operation & 23 & 31.08 \\
Fertilizer application & 59 & 79.72 \\
Use of chemical for weed control & 45 & 60.81 \\
Milling/processing technology & 32 & 43.24 \\
\hline
\end{tabular}

Source: field survey, 2007

Multiple responses 
Journal of Agricultural Extension

Vol. 13 (1) June, 2009

\section{Socio-economic benefits of adoption of rice technologies to the farmers Income}

Table 2 reveals that $81.36 \%$ of the respondents had an increase in personal income. The sampled youths explained that their adoption decisions were mainly based on grains qualities (cleanliness and attractiveness) which attract more monetary value when in market. This result implies that the youths were keeping pace with the improved rice technology practices and were also keen to improve their financial status. Probably because of poor record keeping, $11.86 \%$ of the respondents reported that they did not know whether there was an increase in their income or not.

\section{Health}

From Table 2, 52.54\% of the respondents have their health conditions improved. According to the youths, the sales of improved rice produce assisted them to settle medical bills, provide family source of nutrient such as protein, carbohydrate and other essentials required for a good healthy living. About $28.81 \%$ of the respondents observed no difference in health condition, while $18.65 \%$ said they did not know.

\section{Children education}

The result in Table 2 shows that $47.46 \%$ of the respondents noticed the significance of adoption-decision on their children's education. The respondents explained that the sales of improved rice varieties had helped them in paying children school fees, purchase school materials and other learning necessities. On the other hand, $52.54 \%$ of the respondents reported that adoption decision has nothing to do with their children's education. This may be attributed to lack of adequate awareness on the value of education for the prosperity of the family and hence they may be more concerned with meeting up with other family needs than education.

\section{Yield}

Table 2 indicates that $79.66 \%$ of the respondents had an increase in rice production /ha as a result of their adoption decision, this is expected because of the yielding potentials of the improved varieties. While $15.25 \%$ did not observe any increase in rice yield/ha.

\section{Livestock feed}

Some of the respondents $(69.49 \%)$ reported that improved rice varieties provided good rice straw for feeding livestock such as goats, sheep and cattle particularly during the dry season when cost of feeding the livestock has gone up (Table 2). Considering the sizable number of livestock in the area, this can help cut down the cost of feeding and improve nutritional status of the animals. In fact, some of the respondents said their preference for some improved rice varieties were not based on grains yield alone, but because of their straw yield. 
TABLE 2: Socio-economic benefits of adoption for adopters of rice technologies

\begin{tabular}{lcc}
\hline \multicolumn{1}{c}{ Socio-economic benefits } & Frequency & Percentage \\
\hline & & \\
2.1 Farm income & 48 & 81.36 \\
Increased & 4 & 6.78 \\
No observe increase & 7 & 11.86 \\
Don't know & 59 & 100.00 \\
Total & & \\
2.2 Health condition & 31 & 52.54 \\
Health condition improved & 17 & 28.81 \\
No difference in health condition & 11 & 18.65 \\
Don't know & 59 & 100.00 \\
Total & & \\
2.3 Children education & 28 & 47.46 \\
Encouraged & 31 & 52.54 \\
No difference & 59 & 100.00 \\
Total & & \\
2.4 Rice yield & 47 & 79.66 \\
Noticed yield increase & 9 & 15.25 \\
No difference yield & 3 & 5.09 \\
Notice yield decrease & 59 & 100.00 \\
Total & & \\
2.5 Straw yield & 41 & 69.49 \\
Provide good straw & 18 & 30.51 \\
No difference & 59 & 100.00 \\
Total & & \\
\hline
\end{tabular}

Source: field survey, 2007

Note: Response here is applicable to adopters only; hence, total is 59 respondents

\section{Relationship between Youth's Socio-economic Characteristics and Adoption of Improved Rice Technologies}

From the findings in Table 3, it can be inferred that higher extension contact would increase adoption of improved rice production technologies. Extension workers are supposed to provide farmers with reliable information on a variety of agricultural innovations. The frequency of contact is very essential as it guides the farmers right from awareness to adoption stage. Similarly, membership of cooperative association is expected to influence farmer's desire to adopt innovations. This stems from the fact that members of the association have more access to source of knowledge and information on new technology which can facilitate an improved access to cheaper sources of credit and other important inputs needed in rice production. The Chi-square result in Table 3 also reveals significant relationship between income and adoption, a possible inference from the finding is that respondents with high income because of their potential privileged position to acquire production inputs will be more willing to adopt new technologies and accept higher risk than a low income respondents. 
On the other hand, there was no relationship between education and adoption. Although education increases awareness and prepares people for innovative changes, but Pramanik et al (2001) reported that most farmers at village level are uneducated, and therefore stressed the need to recognize the fact that they can be very efficient in some recommended agricultural innovations, if properly presented to them.

TABLE 3: Relationship between socio-economic characteristics and adoption

\begin{tabular}{lcccl}
\hline $\begin{array}{l}\text { Socio-economic } \\
\text { Characteristics }\end{array}$ & $\begin{array}{l}\text { Degree of } \\
\text { freedom }\end{array}$ & $\begin{array}{l}\text { Critical } \\
\text { value }\end{array}$ & $\begin{array}{c}\text { Obtained } \\
\text { value }\end{array}$ & Decision (0.05) \\
\hline Age & 5 & 11.07 & 10.21 & Not significant \\
Education level & 4 & 9.49 & 8.09 & Not significant \\
Income & 4 & 9.49 & 56.33 & Significant \\
Household size & 2 & 5.99 & 2.15 & Not significant \\
Social participation & 2 & 5.99 & 22.58 & Significant \\
Extension contact & 4 & 9.49 & 21.61 & Significant \\
\hline
\end{tabular}

Source: field survey, 2007

\section{Adoption and Production Constraints}

Result on respondent's constraints indicates that $55.41 \%$ of the respondents had pest problem. The outbreak of qualea birds affected some parts of the area and many farmers lost their rice crop due to pest invasion. Another important problem confronting the youth rice farmers in the area was that of inadequate knowledge on plant spacing and planting time accounting for $45.95 \%$. Due to inadequate knowledge on planting time, the respondents revealed that when the early maturing improved rice varieties are planted early, they mature at the peak of raining season and create threshing and drying problems for them. This was followed by grazing problem as reported by $25.68 \%$ of the respondents. The rice farmers complained that the nomadic Fulani's bring their livestock to the farmlands to graze on rice straws, destroying crops and farmland in the process. Baba and Singh (1996) in a related study, reported that conflicts exists between arable crop farmers and pastoralists which lead to lost of lives and properties in some cases. 
TABLE 4: Distribution of respondents based on adoption/ production constraints

\begin{tabular}{lcc}
\hline Problems & Frequency & Percentage \\
\hline Inadequate knowledge on & & \\
Planting time/ plant spacing. & 34 & 45.95 \\
Flood & 6 & 8.12 \\
Pest problem & 41 & 55.41 \\
Grazing problem & 19 & 25.68 \\
\hline
\end{tabular}

Source: field survey, 2007

Multiple responses

\section{CONCLUSION AND RECOMMENDATIONS}

From the findings of the study, it can be concluded that majority of the youth respondents adopted fertilizer application and improved rice varieties on rice production. Some of the socioeconomic benefits of adoption of rice technologies to the respondents include increase in output and income, improvement in health conditions and provision of livestock feeds. Furthermore, income, extension contact and social participation had significant relationship with adoption, while pest invasion, inadequate knowledge on plant spacing/planting time and grazing problems were the major constraints to adoption and production of rice in the area.

Extension agency and its agents should create more awareness among farmers especially youths on the need to adopt the entire rice technology package for maximum benefit. The awareness can be carried out through village youth associations.

In addition, more promising rice varieties of grains quality and straw yield should be developed to meet farmer's preference and requirements. To provide holistic solution to the problem of pest and inadequate knowledge on plant spacing and planting time reported by the respondents, a team approach to rice extension in which an agronomist, crop pathologist and extension worker visit farmers together, should be introduced. This is necessary because of the special role rice is expected to play in poverty alleviation and food security. There should be a symbiotic relationship between rice farmers and pastoralist. They should met and discuss at village level, the cattle should come in after harvest to graze the residues in so doing, they will stool and leave manure on the farmlands. To facilitate this, community-based farmers and pastoralists conflicts resolution committee should be formed in the area. 


\section{Journal of Agricultural Extension}

Vol. 13 (1) June, 2009

\section{REFERENCES}

Baba, K. M. and Singh, B. R. (1996). "Sustainable Development of the Fadama Lands in Northern Nigeria. A review of the potentials and challenges". Nigeria Journal of Rural Sociology, 2 : 95-105.

Central Bank of Nigeria (1999). Annual Report and Statement for the year ended 31 December 1999.

Imolehin, E. D. (2000). Meeting the Rice Production and Consumption demand of Nigeria with Improve Technology, International Rice Commission Newsletter Vol.49.

National Cereal Research Institute (2004). Training Manual on Rice Production and Processing produced for the Presidential Initiative on Paddy Rice Production For rice mills in the North Central zone of Nigeria held at Baddegi. 1-80pp.

Niger State Agricultural Development Project (1994).Impact Study Final Report 1-128pp

Niger State Government Diary (2003).A yearly publication by the Ministry of Information and Culture, Niger State. Pp. 1-6.

Pramanik, S. C., Sagar, R. L., Singh, B. and Ahmad, Z. (2001). Farmers' Participatory Evaluation of Rice Production Technologies in Bay Island. Int. Rice Res. Notes 26 (2):82-83.

West African Rice Development Association (1996). Rice Friends in Sub-Sahara Africa; A Synthesis of Statistic on Rice production, Trade and Consumption.UK Sayce Publishers. $3 p$. 